\title{
EFFECT OF CORE STABILITY EXERCISE ON CROSS-SECTIONAL AREA OF LUMBAR MULTIFIDUS MUSCLE AND PHYSICAL CAPACITY
}

\author{
Irina Klizienè ${ }^{1}$, Saulè Sipavičienė², Daiva Imbrasiené², Šarūnas Klizas², \\ Hermanas Inokaitis ${ }^{2}$
}

Kaunas University of Technology ${ }^{l}$, Kaunas, Lithuania, Lithuanian Academy of Physical Education', Kaunas, Lithuania

\begin{abstract}
Research background and hypothesis. Our research novelty was the validation of the use of the method of Ultrasound Imaging to measure the changes in the size of the cross-sectional area (CSA) of the multifidus muscle, performing exercises for lumbar stability. Stabilization exercises have been designed in order to enhance the neuromuscular control system correct the dysfunction.

Research aim. The purpose of this study was to establish the effect of core stability exercise for cross-sectional area of lumbar multifidus muscle and physical capacity for elderly women.

Research methods. The elderly women $(\mathrm{n}=22)$ were in occupations involving light or no manual work and did not take part in sports. CSA of the multifidus muscle was measured from L2 to L5 vertebral segments. These measures were taken with ultrasound „TITAN ${ }^{\mathrm{TM}}$ " (SonoSite, USA). For the assessment of physical capacity we estimated the women's static strength endurance of back muscles and dynamic strength endurance of abdominal muscles. The tests were done three times: the first testing occurred before exercises for training lumbar stability, the second - after four months, and the third - after eight months of applying exercises for training lumbar stability.

Research results. The results of study showed that after eight months of stability exercises, the subjects had significantly larger right side multifidus CSA than before practice $-9.01 \pm 1.1$, the left side of the lumbar multifidus muscle was $8.23 \pm 0.9(\mathrm{p}<0.05)$. After the evaluation of physical capacity we revealed that after eight moths it was $97.6 \pm 2.8 \mathrm{~s}$ (very good), compared to the values before the research $(25.4 \pm 9.2)(\mathrm{p}<0.05)$.

Discussion and conclusions. After the core stabilization exercise program multifidus CSA values were significantly larger than before practice, multifidus muscle asymmetry decreased. Physical activity programs adapted to the elderly women increased their physical capacities.
\end{abstract}

Keywords: lumbar stability, physical activity programs, age.

\section{INTRODUCTION}

$\mathrm{E}$ xercises are frequently used by physical therapists for the treatment of low back pain. Specific exercises that activate abdominal and/or back extensor muscles are advocated to reduce pain and disability (Richardson et al., 1999; McGill, 2002). Low back pain is a major problem involving high sport medical costs; therefore effective prevention strategies are essential. Much discussion exists about which is the most effective technique to improve spine stability (Vera-Garcia et al., 2007). The role of exercise and activity in the management of back pain has changed markedly over the last century. Core stability exercise may provide several benefits to the musculoskeletal system, from maintaining low back health to preventing and increasing the cross-sectional area 
(CSA) of lumbar multifidus muscle. Stabilization exercises have been designed in order to enhance the neuromuscular control system and correct the dysfunction. The general conclusion is that exercises are ineffective for acute low back pain or as effective as other treatments, but they are effective for chronic low back pain or even more effective than other treatment. However, there is limited evidence for specific rather than general exercises (Norris, 2000; Stokes et al., 2005). J. A. Hayden (2005) and colleagues performed a meta-analysis looking at exercise intervention types and their effects on pain and disability and concluded that exercise therapy consisting of individually designed programmes, including stretching or strengthening, stabilization exercises delivered with supervision might improve pain reduction in chronic non-specific low-back pain (Hayden et al., 2005).

Several studies examined multifidus muscle size among asymptomatic, healthy persons. Ultrasound Imaging was validated as a noninvasive method to measure the activation of selected muscles (Kiesel et al., 2007). A study of healthy young females using Ultrasound Imaging and Magnetic Resonance Imaging showed that the multifidus was symmetrical between sides at each vertebral level studied (L2-S1) and increased incrementally in size from L2 to L5 (MacDonald et al., 2006). Fifty-one normal subjects were measured using real-time ultrasound imaging at the L4 vertebral level, and in 10 subjects the measurements were made at each vertebral level from L2-S1. A recent study of 120 asymptomatic subjects provided reference ranges for the lumbar multifidus at the L4 and L5 vertebral levels across various age ranges using real-time Ultrasound Imaging (Hides et al., 1995). Results showed that lumbar multifidus CSA was larger in males, and age had no effect on multifidus muscle size. In agreement with the previous studies, between-side symmetry was high for lumbar multifidus muscle size (CSA 10\% between - side differences).

Elderly aging is accompanied by several morphological, physiological and biochemical alterations. Among these alterations, muscular strength, flexibility, balance and physical conditioning deficits can be highlighted (Zhong et al., 2007). The flexibility loss in the elderly people changes the walking pattern in relation to the step's amplitude and the balance, harming the functional independence and increasing the risk of falls (Fraga et al., 2011). With aging the nervous system presents neuronal loss and a decrease in the nervous conduction velocity, a fact that compromises the good behavior of the systems responsible for the postural control (Jankelowitz et al., 2007). The $\mathrm{VO}_{2} \max$ presents a reduction of $0.4-0.5 \mathrm{ml} /(\mathrm{kg} / \mathrm{min})$ in each year of sedentary women's life, representing a loss of 50\% from the thirties to the eighties (Hagberg, 1989). Physical activity programs adapted to elderly people have been implemented in Lithuania with the intention of minimizing the alterations provoked by aging. Several studies demonstrated the efficacy of these programs in the improvement or maintenance of muscular strength, flexibility, balance, physical conditioning and body weight (Hauer et al., 2006).

In Lithuania the diagnostic method of Ultrasound Imaging has not been widely used for the measurement of changes in the size of the cross-sectional area of the multifidus muscle or for obtaining feedback in the rehabilitation of lumbar pain performing exercises meant for lumbar stability as well as establishing indices of physical development and physical capacity. Thus, there is not much research on those issues. The purpose of this study was to establish the effect of core stability exercise for cross-sectional area of lumbar multifidus muscle and physical capacity for elderly women.

\section{RESEARCH METHODS}

The subjects were either sedentary or moderately active females. The elderly women $(n=22)$ were in occupations involving light or no manual work and did not take part in sports. Their age was $64.8 \pm 5.4$ years, body weight $-67.6 \pm 4.2 \mathrm{~kg}$, height $165.7 \pm 8.9 \mathrm{~cm}$, and body fat $-28.9 \pm 11.3 \%$ (body fat mass $-19.6 \pm 9.1 \mathrm{~kg}$ ). Each subject read and signed a written informed consent form consistent with the principles outlined in the Declaration of Helsinki. Ethical approval was obtained from Kaunas Regional Biomedical Research Ethics Committee (Report Number BE-2-24).

Testing and assessment of multifidus muscle CSA. CSA of the multifidus muscle was measured from L2 to L5 vertebral segments with ultrasound "TITAN ${ }^{\mathrm{TM}}$ " (SonoSite, USA). The resultant image was displayed on the screen (Figure 1) from which multifidus CSA were determined using electronic calipers. This process was repeated for each subsequent vertebral segment. Bilateral images of the multifidus muscles were obtained where possible except for the cases of larger subjects where left and right sides were imaged separately (Hides et al., 2008 a) (Figure 1). The subjects were 

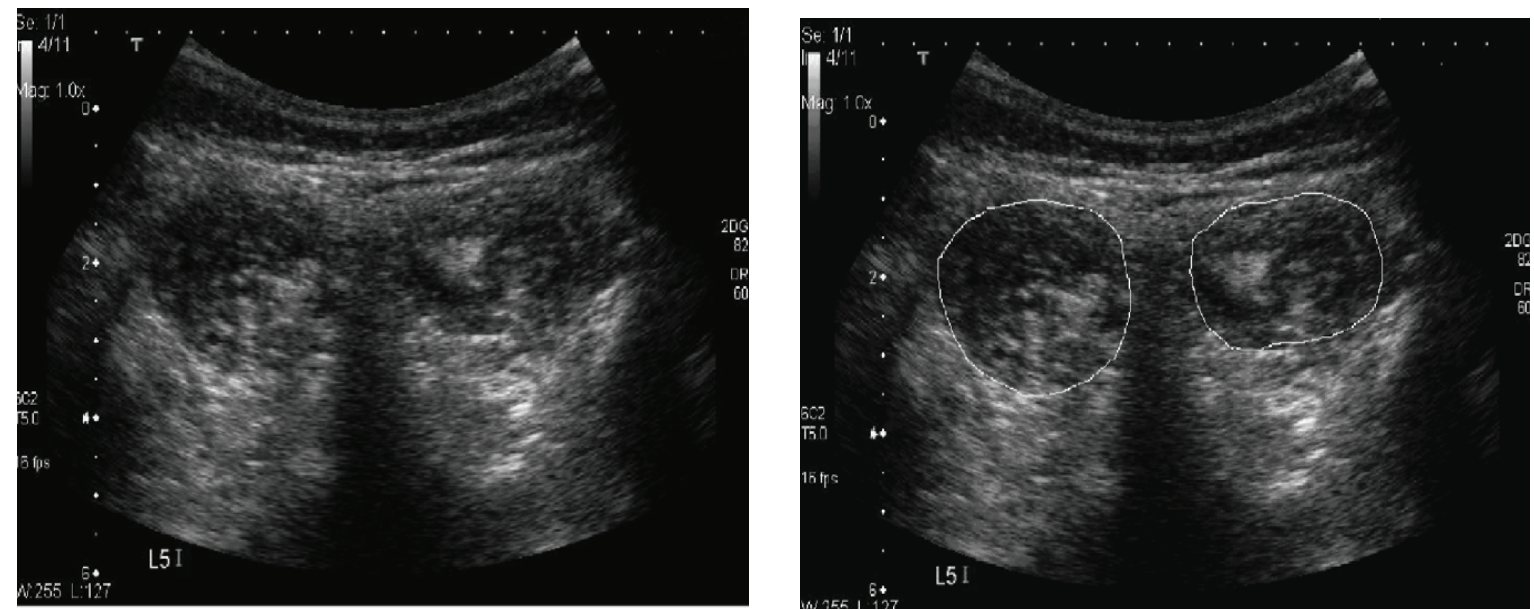

Figure 1. Bilateral transverse image at the L5 vertebral level showing atrophy of the right lumbar multifidus muscle, with and without CSA tracings (Hides et al., 2008 a)

instructed to relax their paraspinal musculature, electro conductive gel was applied, and the transducer placed transversely over the spinous process of the vertebral level which was measured. This produced images in which the spinous process and laminate could be seen, with multifidus muscles visible on both sides of the spine. The CSA of the multifidus was measured by tracing around the muscle border with the on-screen cursor. The CSA of the multifidus muscle percentage expression of symmetry was calculated following the recommendations in research literature.

Physical capacity. Keeping the trunk in the horizontal position with the face down. This test was used to evaluate the static strength endurance of back muscles. The subject had to lie on a gymnastic bench so that her pelvic bones protruded over the edge of the bench, hands on the floor, and then the partner held the legs tight on the bench. After the start signal the subject had to clasp hands behind neck and keep the trunk in a horizontal position. We registered how much time the subject was able to keep the body in a horizontal position. The evaluation of females was as follows: very good $-86 \mathrm{~s}$ and more, good $-71-85 \mathrm{~s}$, moderate $41-70 \mathrm{~s}$, worse that moderate $-26-40 \mathrm{~s}$, poor $-25 \mathrm{~s}$ and less (Volbekienè, 2003).

For the evaluation of the dynamic strength endurance of abdominal muscles we applied the "sit up" test. The subject lied on the floor with legs bent at the angle of $90^{\circ}$ and hands clasped behind the neck, the partner held the feet. The test lasted for $30 \mathrm{~s}$ (the subjects had to perform as many sit ups as they could without resting) (Volbekiene, 2003).

Exercises in the testing procedure. Six exercises (often used in clinical practice to train lumbar stability) were performed. The group of exercises was executed in supine position, knees bent $\left(60^{\circ}\right.$ flexion) and feet on the floor. The following exercises was performed in fourpoint kneeling. At the start of each exercise, the examiner determined the subject's lumbar neutral spine position and the subjects were asked to hold this position throughout the exercise. The exercises were performed in a random sequence. In order to standardize the position of the subject and the equipment, markers were placed on the floor. The dynamic phases (i. e. lifting and lowering of the pelvis and the extremities) lasted for $2 \mathrm{~s}$. The midphase (i. e. extended leg/arm and lifted pelvis) was held for $5 \mathrm{~s}$. The rhythm of 60 beats/min was set by a metronome. For each exercise three trials were performed. To prevent muscular fatigue, an interval of at least $15 \mathrm{~s}$ was allowed between the exercises; during these periods the exercises were explained. At the start of each exercise, the examiner determined the subject's lumbar neutral spine position and the subjects were asked to hold this position throughout the exercise.

Research protocol. The tests were done three times: the first testing occurred before exercises of training lumbar stability, the second - after four moths, and the third - after eight months of applying exercises for training lumbar stability. The subjects were engaged in an eight-month exercise program of training lumbar stability (two times per week, $45 \mathrm{~min}$ in each practice session). At the beginning of the research, after four moths and at the end of the research the women underwent the measurement of the cross-sectional area of the multifidus muscle. For the assessment of physical capacity we estimated the women's static strength endurance of back muscles and dynamic strength endurance of abdominal muscles. 
Statistical analysis. Research data were processed by methods of descriptive statistics and more complicated statistics using program packages Microsoft ${ }^{\circledR}$ Excel 2007 and SPSS 13. The significance of mean differences was assessed using two-sided Student's $t$ test for independent samples. The CSA of the multifidus muscle percentage expression of symmetry was calculated following the recommendations in research literature (Stokes et al., 2005).

\section{RESEARCH RESULTS}

Research findings showed that after stability exercises the subjects had significantly larger multifidus CSA than before stability exercises.

Before stability exercises, CSA of the right side of the lumbar multifidus muscle was $4.92 \pm 1.3$, and the left side of the lumbar multifidus muscle was
$5.32 \pm 1.4$. After 4 months, when the subjects had worked out in the group exercises (core stability exercises), CSA was significantly larger: the right side of the lumbar multifidus muscle was $6.91 \pm 1.3$; the left side $-5.97 \pm 1.5(\mathrm{p}<0.05)$. However after 8 months of stability exercises, the subjects had significantly larger right side multifidus CSA than before practice $-9.01 \pm 1.1$, the left side of the lumbar multifidus muscle was $8.23 \pm 0.9(\mathrm{p}=0.05)$ (Figure 2).

Before and after the lumbar core stabilization program, we evaluated the size of multifidus CSA between the left and the right sides. Figure 3 presents the mean percentage value of this index.

Before the lumbar core stabilization program the CSA of females was $39.22 \pm 6.9 \%$, after the lumbar core stabilization program a statistically significant $(\mathrm{p}<0.05)$ decrease of CSA $(32.51 \pm 7.8 \%)$ was established.
Figure 2. Cross-sectional area (left and right sides) of lumbar multifidus muscles
Note. $* * *-p=0.05$ statistically significant differences in the values of the right and the left sides before and after eight months. $* * *, * * * *$ $\mathrm{p}=0.05$ statistically significant differences in the values of the right and the left sides after four and after eight months.

Figure 3. Lumbar multifidus muscle asymmetry

Note. ${ }^{*}-\mathrm{p}=0.05$ significant decrease in CSA asymmetry comparing the indices before and after eight months.
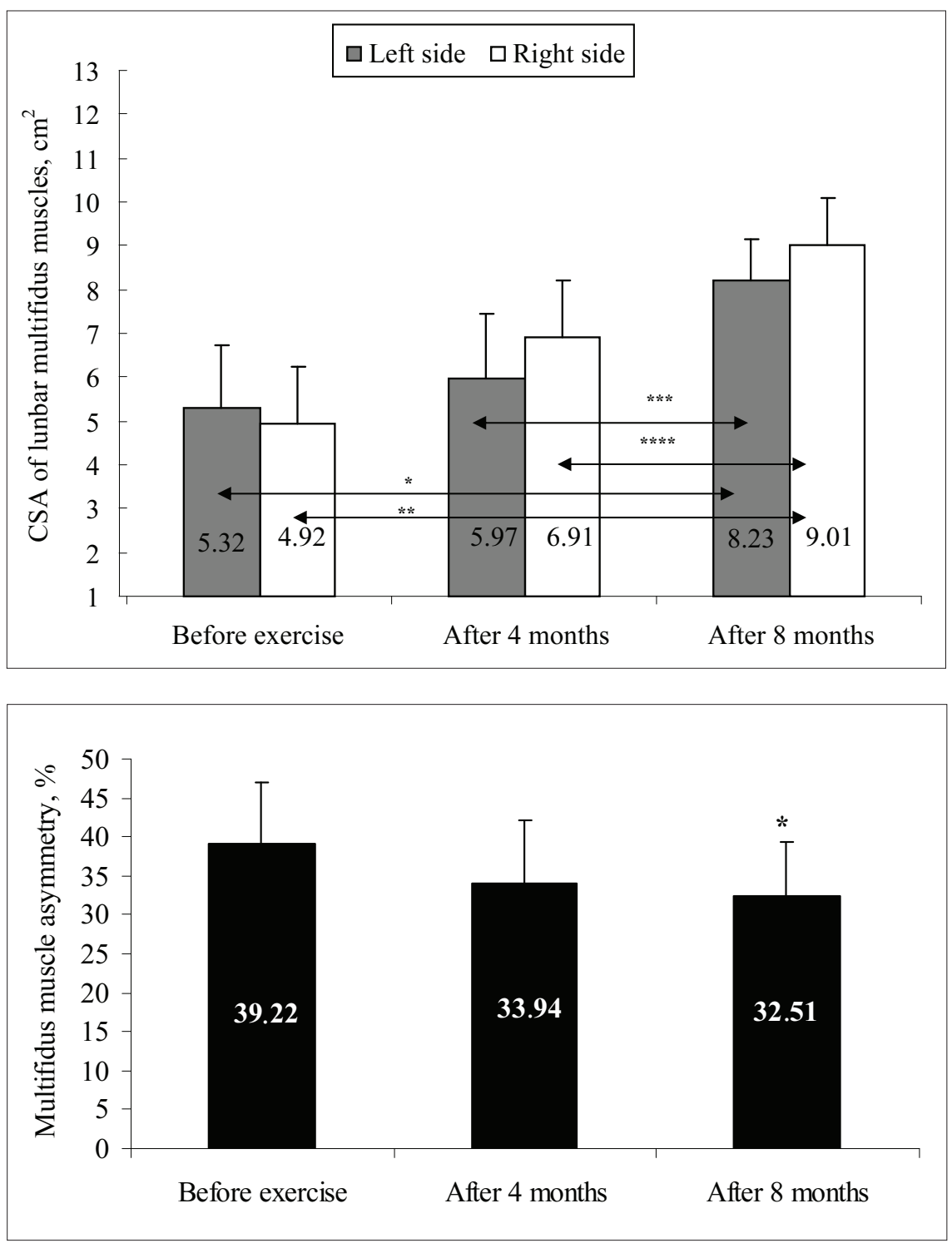
Table. Physical capacity indices before stability exercise, after four and eight months

\begin{tabular}{|c|c|c|c|c|}
\hline Physical capacity indicator & Before exercise & After 4 months & After 8 months & p-value \\
\hline $\begin{array}{c}\text { Dynamic strength endurance of } \\
\text { abdominal muscles }\end{array}$ & $\begin{array}{c}25.4 \pm 9.2 \mathrm{~s} \\
\text { (bad) }\end{array}$ & $\begin{array}{c}75.4 \pm 4.4 \mathrm{~s}^{*} \\
\text { (good) }\end{array}$ & $\begin{array}{c}97.6 \pm 2.8 \mathrm{~s} * \\
\text { (perfect) }\end{array}$ & 0.05 \\
\hline $\begin{array}{c}\text { Static strength endurance of back } \\
\text { muscles }\end{array}$ & $\begin{array}{c}15.3 \pm 6.2 \\
\text { (moderate) }\end{array}$ & $\begin{array}{c}17.7 \pm 3.1 \\
\text { (moderate) }\end{array}$ & $\begin{array}{c}25.6 \pm 4.1 * \\
\text { (higher than moderate) }\end{array}$ & 0.05 \\
\hline
\end{tabular}

Note. ${ }^{*}-\mathrm{p}=0.05$ significant increase compared to the values before stability exercise.

After the evaluation of physical capacity we revealed that after 4 months of exercising the static strength endurance of back muscles keeping the trunk in a horizontal position face down improved $(75.4 \pm 4.4 \mathrm{~s}$ (good)), and after 8 moths $-97.6 \pm 2.8 \mathrm{~s}$ (very good), compared to the values before the research $(25.4 \pm 9.2)(\mathrm{p}<0.05)$ (Table).

The evaluation of the dynamic strength endurance of abdominal muscles showed that after the 8-month core stabilization exercise program the index values of women $(25.6 \pm 4.1$, better than moderate) were better compared to the initial values before the research $(15.3 \pm 6.2$, moderate) $(\mathrm{p}<0.05)$. However, after the 4-months core stabilization exercise program we did not establish any statistically significant difference $(\mathrm{p}>0.05)$ (Table).

\section{DISCUSSION}

Research results showed that after stability exercises the subjects had significantly larger multifidus CSA than before practice. After the core stabilization exercise program multifidus muscle asymmetry increased, physical capacities improved.

One of the most effective types of exercise is core muscle strengthening. This form of exercise concentrates on the abdominal and lower back muscles. The advantage of this form of exercise is that it can reduce lower back pain and reduce back injury by allowing proper alignment of the spinal column. Furthermore, functional reach can be increased with good core strengthening, reducing the risk of falling, especially in the elderly (Stokes et al., 2005). Classic trunk strengthening exercises involve activation of abdominal and paraspinal musculature at high levels of contraction. Such gross strengthening exercises differ from stability exercises in which there is preferential training to stabilize muscles, initially with low level isometric activation followed by progressive integration into everyday activities (Richardson et al., 1999; Norris, 2000). If performed incorrectly, classic trunk strengthening exercises may lead to inappropriate muscle coordination patterns and increased risk of further injury (Richardson et al., 1999, Cholewicki, McGil, 1996). In addition, exercises that are said to preferentially select transversus abdominus and multifidus, as described by C. Richardson et al. (1999) and P. B. O'Sullivan et al. (1997) are distinguished (MacDonald et al., 2006) from general trunk stabilization exercises, as described by S. McGill (2002). Decreased lumbar multifidus muscle activation is associated with the presence of factors predictive of clinical success with a stabilization exercise program (Hebert et al., 2010). J. A. Hides_et al. (2008 b) found that the CSA of the multifidus muscles at the L5 vertebral level increased for the 7 cricketers with low back pain who received the stabilization training, compared to the 14 cricketers without low back pain who did not receive rehabilitation $(\mathrm{p}=0.004)$. In addition, the amount of muscle asymmetry among those with low back pain significantly decreased $(p=0.029)$ and became comparable to cricketers without low back pain. These effects were not evident for the L2, L3, and L4 vertebral levels. Multifidus muscle atrophy can exist in highly active, elite athletes with low back pain. Specific retraining resulted in an improvement in multifidus muscle CSA and this was concomitant with a decrease in pain. However L. A. Danneels et al. (2001) found that general stabilization exercises and dynamic intensive lumbar resistance training had no significant effect on the CSA of the lumbar multifidus muscle in patients with low back pain. The static holding component between the concentric and eccentric phase was found to be critical in inducing muscle hypertrophy during the first 10 weeks. Treatment consisting of stabilization training combined with an intensive lumbar dynamic-static strengthening programme seems to be the most appropriate method of restoring the size of the multifidus muscle.

Physical activity programs adapted to the elderly women have been proposed with the purpose of minimizing the alterations provoked by aging (Greve et al., 2009). We could see that after the core stabilization exercise program physical capacities 
were better for elderly women. I. G. Fatouros et al. (2005) verified that high intensity exercises for elderly women might maintain the strength gain, aerobic power and mobility for longer periods after ceasing the low intensity exercises. F. X. Gamelin et al. (2007) investigated the effects of 12 weeks of training and 8 weeks of lack of training on the heart frequency variability and on the $\mathrm{VO}_{2}$ max and observed that the last one decreased significantly between the second and the eighth weeks. The authors concluded that 8 weeks of lack of training allowed a reverse of the cardiovascular adaptations induced by 12 weeks of training on elderly women.

\section{CONCLUSION AND PERSPECTIVES}

After the core stabilization exercise program multifidus CSA was significantly larger than before practice, multifidus muscle asymmetry increased. Physical activity programs adapted to the elderly women increased physical capacities. Further research is needed to evaluate the effectiveness of stabilization techniques and expectation for ensuring spinal stability when the healthy or unstable spine is loaded in different directions, postures and motions.

\section{REFERENCES}

Cholewicki, J., McGil, S. M. (1996). Mechanical stability of the in vivo lumbar spine: Implications of injury and chronic low back pain. Clinical Biomechanics, 11, 1-15.

Danneels, L. A., Vanderstraeten, G. G., Cambier, D. C. et al. (2001). Effects of three different training modalities on the cross sectional area of the lumbar multifidus muscle in patients with chronic low back pain. British Journal of Sports Medicine, 35, 186-191.

Fatouros, I. G., Kambas, A., Katrabasas, I. et al. (2005). Strength training and detraining effects on muscular strength, anaerobic power, and mobility of inactive older men are intensity dependent. British Journal of Sports Medicine, 39, 776-780.

Fraga, M. J., Cader, S. A., Ferreira, M. A. et al. (2011). Aerobic resistance, functional autonomy and quality of life (QoL) of elderly women impacted by a recreation and walking program. Archives of Gerontology and Geriatrics, 52 (1), 40-43.

Gamelin, F. X., Berthoin, S., Sayah, H. et al. (2007). Effect of training and detraining on heart rate variability in healthy young men. International Journal of Sports Medicine, 28, 564-570.

Greve, P., Wanderley, F. S., Rebelatto, J. R. (2009). The effects of periodic interruptions of physical activities on the physical capacities of adult active women. Archives of Gerontology and Geriatrics, 49, 268-271.

Hagberg, J. M. (1989). Cardiovascular response of 70-79-year-old men and women to exercise training. Journal of Applied Physiology, 66, 2589-2594.

Hauer, K., Becker, C., Lindemann, U., Beyer, N. (2006). Effectiveness of physical training on motor performance and fall prevention in cognitively impaired older persons: A systemic review. American Journal of Physical Medicine and Rehabilitation, 85, 847-857.

Hayden, J. A., van Tulder, M. W., Malmivaara, A., Koes, B. W. (2005). Exercise therapy for treatment of non-specific low back pain. The Cochrane Database of Systematic Reviews [electronic resource], 20 (3), CD 000335.
Hebert, J. J., Koppenhaver, S. L., Magel, J. S., Fritz, J. M. (2010). The relationship of transversus abdominis and lumbar multifidus activation and prognostic factors for clinical success with a stabilization exercise program: A cross-sectional study. Archives of Physical Medicine and Rehabilitation, 91, 78-85.

Hides, J. A., Gilmorea, C., Stanton, W., Bohlscheid, E. (2008 a). Multifidus size and symmetry among chronic LBP and healthy asymptomatic subjects. Manual Therapy, 13, 43-49.

Hides, J. A., Richardson, C. A., Jull, G. A. (1995). Magnetic resonance imaging and ultrasonography of the lumbar multifidus muscle-comparison of two different modalities. Spine, 20, 54-58.

Hides, J. A., Stanton, W. R., McMahon, S. et al. (2008 b). Effect of stabilization training on multifidus muscle cross-sectional area among young elite cricketers with low back pain. Journal of Orthopaedic and Sports Physical Therapy, 38, 101-108.

Jankelowitz, S. K., McNulty, P. A., Burke, D. (2007). Changes in measures of motor axon excitability with age. Clinical Neurophysiology, 118, 1397-1404.

Kiesel, K. B., Uhl, T. L., Underwood, F. B. et al. (2007). Measurement of lumbar multifidus muscle contraction with rehabilitative ultrasound imaging. Manual Therapy, 12, 161-166.

MacDonald, D. A., Moseley, G. L., Hodges, P. W. (2006). The lumbar multifidus: Does the evidence support clinical beliefs? Manual Therapy, 11, 254-263.

McGill, S. (2002). Low Back Disorders. Evidence-based Prevention and Rehabilitation. Champaign: Human Kinetics.

Norris, C. M. (2000). Back Stability. Champaign: Human Kinetics.

Richardson, C., Jull, G., Hodges, P., Hides, J. (1999). Therapeutic Exercises for Spinal Segmental Stabilization in Low Back Pain. Edinburgh: Churchill Livingstone. 
Stokes, M., Rankin, G., Newham, D. J.(2005). Ultrasound imaging of lumbar multifidus muscle: Normal reference ranges for measurements and practical guidance on the technique. Manual Therapy, 10 (2), 116-126.

O’Sullivan, P. B., Twomey, L. T., Allison, G. T. (1997). Evaluation of specific stabilizing exercise in the treatment of chronic low back pain with radiologic diagnosis of spondylolysis or spondylolisthesis. Spine, 22, 2959-2967.

Vera-Garcia, F. J., Elvira, J. L. L., Brown, S. H. M. M., McGill, S. M. (2007). Effects of abdominal stabilization maneuvers on the control of spine motion and stability against sudden trunk perturbations. Journal of Electromyography and Kinesiology, 17, 556-567.

Volbekienè, V. (2003). Eurofitas. Fizinio pajègumo testai ir metodika. Vilnius: LSIC. P. 109-125.

Zhong, S., Chen, C. N., Thompson, L. V. (2007). Sarcopenia of ageing: Functional, structural and biochemical alterations. Revista Brasileira de Fisioterapia, 11, 91-97.

\title{
STUBURO STABILIZAVIMO PRATIMŲ POVEIKIS DAUGINIO RAUMENS SKERSPJŪVIO PLOTO IR FIZINIO PAJĖGUMO KAITAI
}

\author{
Irina Klizienė', Saulẻ Sipavičienė , Daiva Imbrasienè², Šarūnas Klizas², \\ Hermanas Inokaitis ${ }^{2}$ \\ Kauno technologijos universitetas ${ }^{1}$, Kaunas, Lietuva \\ Lietuvos kūno kultūros akademija², Kaunas, Lietuva
}

\section{SANTRAUKA}

Tyrimo pagrindimas ir hipoteze. Tyrimo naujumas: ultragarinės diagnostikos metodu buvo matuojamas dauginio raumens skerspjūvio plotas, stebimi jo pokyčiai atliekant pratimus, kuriais siekiama stabilizuoti juosmeninę stuburo dalị.

Tikslas: nustatyti stuburo stabilizavimo pratimų poveiki vyresniojo amžiaus moterų dauginio raumens skerspjūvio ploto ir fizinio pajègumo kaitai.

Metodai. Tiriamujų kontingentą sudare 22 moterys, jaučiančios nespecifini juosmeninès stuburo dalies skausmą. Dauginio raumens skerspjūvio plotas matuotas naudojant ultragarsinę diagnostinę aparatūrą „TITAN ${ }^{\mathrm{TM}}$ ” (SonoSite, JAV), lygiagrečiai ultragarsu buvo nuskaitoma abiejose stuburo pusėse, ties L2-L5 slanksteliais. Nustatant fizini pajègumą vertinta pilvo preso raumenų dinaminè jèga ir nugaros raumenų statinès jègos ištvermè. Tirta tris kartus: pirmas tyrimas atliktas prieš stuburo stabilizavimo pratimus, antras - po keturių, trečias - po aštuonių mėnesių stuburo stabilizavimo pratimų programos.

Rezultatai. Po aštuonių ménesių stuburo stabilizavimo pratimų programos tiriamujų dešinès $(9,01 \pm 1,1)$ ir kairès $(8,23 \pm 0,9)$ pusès dauginio raumens skerspjūvio plotas statistiškai reikšmingai $(\mathrm{p}<0,05)$ padidejjo, nugaros raumenų statinès jègos ištvermè buvo geresnè $(97,6 \pm 2,8 \mathrm{~s}$ (labai gerai)) negu prieš tyrimą $(25,4 \pm 9,2 \mathrm{~s})(\mathrm{p}<0,05)$.

Aptarimas ir išvados. Atliekant stuburo stabilizavimo pratimus, dauginio raumens skerspjūvio plotas padidèjo, asimetrija - sumažèjo, pagerèjo tirtų moterų fizinio pajègumo rodikliai.

Raktažodžiai: stuburo stabilizavimas, fizinio aktyvumo programa, amžius.

\author{
Kaunas University of Technology \\ Donelaičio str. 73, LT-44248 Kaunas \\ Lithuania \\ Tel +370 37453511 \\ E-mail irina.ramanauskiene@ktu.lt
}

